\title{
HUBUNGAN PEMBENTUKAN BIOFILM OLEH BAKTERI GRAM NEGATIF DENGAN RESISTENSI ANTIBIOTIK PADA WANITA DIABETES MELITUS TIPE 2
}

\author{
Juwita Sahputri ${ }^{1}$, Dharma Lindarto ${ }^{2}$, Ratna Akbari Ganie ${ }^{3}$

\begin{abstract}
${ }^{1}$ Alumni of the Tropical Medicine Masters Study Program, Faculty of Medicine, University of North Sumatra ${ }^{2}$ Teaching staff of Internal Medicine Specialist Education Program Faculty of Medicine, University of North Sumatra ${ }^{3}$ Teaching Staff of Clinical Pathology Specialist Medical Education Program, Faculty of Medicine, University of North Sumatra
\end{abstract}

*Corresponding Author: juwita.sahputri@gmail.com

\begin{abstract}
Abstrak
Diabetes melitus (DM) memiliki efek jangka panjang terhadap sistem genitourinari yang menjadi faktor predisposisi terjadinya infeksi saluran kemih (ISK) pada pasien wanita dan umumnya bersifat asimtomatik. Bakteri gram negatif merupakan mikroorganisme penyebab tersering yang dapat membentuk biofilm sehingga sering menyebabkan resistensi antibiotik. Penelitian ini bertujuan untuk membuktikan hubungan antara pembentukan biofilm bakteri gram negatif dengan resistensi antibiotik pada wanita diabetes melitus tipe 2 (DMT2). Menggunakan desain penelitian cross sectional dengan teknik total sampling. Jumlah sampel penelitian adalah 45 orang wanita DMT2 anggota Program Pengendalian Penyakit Kronis (PROLANIS). Pada semua responden dilakukan kultur urin porsi tengah, uji sensitivitas dan pemeriksaan biofilm terhadap isolat bakteri yang teridentifikasi. Hasil kultur urin menunjukkan bakteriuria signifikan 14 (31\%) responden. Identifikasi koloni menunjukkan bakteri penyebab ISK antara lain Escherichia coli (35,7\%), Klebsiella pneumoniae (35,7\%), Enterobacter sp (21,5\%) dan Citrobacter sp (7,1\%). Uji sensitivitas dijumpai 8 (57\%) isolat resisten terhadap antibiotik, yaitu $2(14,2 \%)$ isolat terhadap ciprofloksasin dan $6(42,8 \%)$ isolat terhadap TMP-SMX. Bakteri gram negatif yang diisolasi 100\% mampu membentuk biofilm dengan kategori weak. Berdasarkan analisis bivariat dengan uji Rank Spearman correlation dapat disimpulkan bahwa terdapatnya hubungan yang sangat lemah antara pembentukan biofilm oleh bakteri gram negatif dengan resistensi antibiotik ciprofloksasin dan TMP-SMX.
\end{abstract}

Kata kunci: bakteri-gram-negatif; biofilm; DM; resistensi-antibiotik

\section{RELATIONSHIP BETWEEN THE FORMATION OF BIOFILM BY GRAM NEGATIVE BACTERIA WITH ANTIBIOTIC RESISTANCE IN WOMEN WITH TYPE 2 DIABETES MELITUS}

\begin{abstract}
Diabetes Mellitus (DM) has a long-term effect on the genitourinary system that predisposes to urinary tract infection (UTI) in female patients and is generally asymptomatic. Gram-negative bacteria are the most common cause of microorganisms that can form biofilms that often cause antibiotic resistance. This study aims to prove the relationship between the formation of biofilms of gram-negative bacteria and antibiotic resistance in women with type 2 diabetes mellitus (DM T2). Using cross sectional research design with total sampling technique. The number of research samples is 45 women DM T2 PROLANIS member. In all respondents, the middle portion of urine culture, sensitivity test, and biofilm examination on identified bacterial isolates were identified. Result of urine culture showed significant bacteriuria $14(31 \%)$ respondents. Identification of colonies showed that UTI bacteria were Escherichia coli (35,7\%), Klebsiella pneumoniae (35,7\%), Enterobacter sp (21,5\%) and Citrobacter sp (7,1\%). Sensitivity test found $8(57 \%)$ isolates resistant to antibiotic, ie $2(14,2 \%)$ isolate to ciprofloxacin and $6(42,8 \%)$ isolate to TMP-SMX. Gram-negative bacteria isolated $100 \%$ are able to form biofilms with the weak category. Bivariate analysis with Rank Spearman correlation test on biofilm formation relationship with antibiotic resistance can be concluded that there is very weak relation $(r<0,25 ; p>$ $0,05)$ between biofilm formation by gram negative bacteria with antibiotic resistance of ciprofloxacin and TMP-SMX.
\end{abstract}

Keywords: gram-negative-bacteria; biofilm;DM; antibiotic-resistance

Jurnal Averrous Vol.4 No.1 2018 


\section{Pendahuluan}

Diabetes is a major cause of morbidity and mortality and is one of the four priorities of noncommunicable diseases. The World Health Organization (WHO) estimates the number of DM patients worldwide to increase to 642 million by $2040^{1,2}$. DM disease has long-term effects on the genitourinary system, thus predisposing to urinary tract infection (UTI) in DM patients ${ }^{3}$.

Urinary tract infections are more common in women than men with a percentage of $52.8 \%$ and $47.2 \%$, respectively. This is because anatomically, women have a shorter urethra than men, urethral orifice and vagina is also an area that easily becomes a place of bacterial colonization ${ }^{4}$. Urinary tract infections in DM women are reported to be more frequent asymptomatic UTIs ${ }^{3,5}$. The prevalence of asymptomatic UTI is about 3-4 times higher in diabetic women (ranging from 15\% $30 \%$ ) than women without DM by $2-5 \%{ }^{15}$.

Gram-negative bacteria is the most commonly microorganism isolated from urine of diabetic patients as the cause of UTI from gram-positive bacteria with gram-negative ratio of $63.64 \%$ while $36.36 \%$ gram-positive. The most common cause of gram-negative bacteria is Escherichia coli, followed by other Enterobacteriae such as Klebsiellapneumoniae., Proteusspp., dan Enterobacterspp 6,7 . Gram-negative bacteria are able to form biofilms coated by uroplakin so that their pathogenicity increases. This ability causes urinary tract infections to become persistent, recurrent and leads to bacteria more resistant to phagocytosis and 100-1000 times more resistant to antibiotics ${ }^{8}$.

\section{Methods}

The research design used was analytical descriptive with cross sectional approach. The samples in this study were diabetes mellitus type 2 / DMT2 PROLANIS member (Chronic Disease Control Program) at Mon Geudong Lhokseumawe Public Health Center amounted to 45 people, using total sampling with inclusion criteria: 1) Female patient with DM T2 PROLANIS member who has been diagnosed by physician as a DM patient and routinely seek treatment at Puskesmas and willing to be a respondent, 2) Have no symptoms of UTI such as dysuria, frequency, urgency, fever etc. 3) No use of antibiotic therapy in the last 2 weeks, 4) Not pregnant. Exclusion criteria are 1) DM patients with accompanying diabetic nephropathy and chronic renal disease, 2) Inpatient history and urinary catheterization in the last 3 months.

Mid-stream urine is collected sterile, then cultured on Mc Conkay and CLED (Cysteine Lactose Electrolyte Deficient). Samples with significant bacteriuria ( $>10^{5} \mathrm{cfu} / \mathrm{ml}$ urine) will be continued for identification of gram-negative bacteria by biochemical test. The sensitivity test of antibiotic ciprofloxacin and trimethoprim-sulfamethoxazole (TMP-SMX) was done by Kirby Bauer 
disc diffusion method, biofilm formation test using Tissue Culture Plate method and reading with $570 \mathrm{~nm}$ wavelength ELISA reader (OD570nm). Bivariate analysis using Rank Spearman test with 95\% significance level $(\alpha=0,05)$.approval of ethical clearance by the Medical Research Ethics Commission (KEPK) of the Faculty of Medicine, University of North Sumatra.

\section{Result}

Table 1 Characteristics of Respondents withand without asymptomatic UTI

\begin{tabular}{|c|c|c|c|c|}
\hline \multirow{2}{*}{ Characteristics of Respondents } & \multicolumn{4}{|c|}{ Urinary Tract Infection } \\
\hline & Negative (n) & $\%$ & Positive (n) & $\%$ \\
\hline \multicolumn{5}{|l|}{ Age } \\
\hline$<50$ years & 5 & 50 & 5 & 50 \\
\hline$\geq 50$ years & 26 & 74,3 & 9 & 25,7 \\
\hline \multicolumn{5}{|l|}{ History DM } \\
\hline$<5$ years & 15 & 65,2 & 8 & 34,8 \\
\hline$\geq 5$ years & 17 & 73,9 & 6 & 26,1 \\
\hline \multicolumn{5}{|l|}{ BMI $(\mathrm{kg} / \mathrm{m} 2)$} \\
\hline Non overweight & 13 & 76,5 & 4 & 23,5 \\
\hline Overweight & 18 & 64,3 & 10 & 35,7 \\
\hline \multicolumn{5}{|l|}{ Sexual Activity } \\
\hline No & 13 & 76,5 & 4 & 23,5 \\
\hline$<3$ times a week & 16 & 64 & 9 & 36 \\
\hline$\geq 3$ times a week & 2 & 66,7 & 1 & 33,3 \\
\hline \multicolumn{5}{|l|}{ Abdominal Circumference } \\
\hline$\leq 80 \mathrm{~cm}$ & 2 & 66,7 & 1 & 33,3 \\
\hline$>80 \mathrm{~cm}$ & 29 & 69 & 13 & 31 \\
\hline \multicolumn{5}{|l|}{ Menstruation } \\
\hline Still & 8 & 61,5 & 5 & 28,1 \\
\hline Stop & 23 & 71,8 & 9 & 28,2 \\
\hline
\end{tabular}

Table 1 shows the respondents with asymptomatic UTIs having age $\geq 50$ years is $25.7 \%$, history / duration of DM $<5$ years $34.8 \%$, overweight BMI $35.7 \%$, sexual activity $<3$ times per week

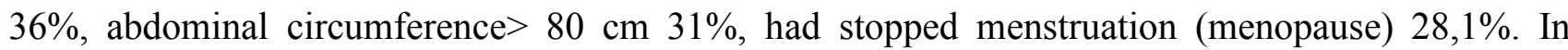
respondents without asymptomatic UTI, the history / duration of DM was $\geq 5$ years with $77.3 \%$ percentage.

Table 2 Distribution Frequency of Patient withAsymptomatic UTI

\begin{tabular}{ccc}
\hline Asymptomatic UTI & Frequence & Percentage \\
\cline { 2 - 3 } & $\mathbf{N}$ & $\mathbf{\%}$ \\
\hline Positive & 14 & 31 \\
Negative & 31 & 69 \\
\hline Total & 45 & 100 \\
\hline
\end{tabular}


Table 2 shows that there were 14 urine samples (31\%) with significant bacteriuria $>105 \mathrm{cfu} /$ $\mathrm{ml}$ urine and 31 other urine samples $(68.9 \%)$ found no bacterial growth at all. The incidence of asymptomatic UTI in women DM T2 was found to be $31 \%$.

Table 3. Profile of Gram Negative Bacteria Causes of Asymptomatic UTI

\begin{tabular}{lcc}
\hline \multirow{2}{*}{ Bacterial Profile } & \multicolumn{2}{c}{ Subjects with Significant Bacteriuria $(\mathbf{n}=\mathbf{1 4})$} \\
\cline { 2 - 3 } & $\mathbf{N}$ & $\mathbf{\%}$ \\
\hline E. coli & 5 & 35,7 \\
K. pneumoniae & 5 & 35,7 \\
Enterobacter $s p$ & 3 & 21,5 \\
Citrobacter $s p$ & 1 & 7,1 \\
\hline Total & 14 & 100 \\
\hline
\end{tabular}

Table 3 shows the dominant bacteria causing asymptomatic UTI in this study were E. coli (35.7\%) and K. pneumoniae (35.7\%), followed by Enterobacter $s p(21.5 \%)$ and Citrobacter $s p$ (7.1\%).

Table 4 Sensitivity of Antibiotics Ciprofloxacin and TMP-SMX

\begin{tabular}{|c|c|c|c|c|c|c|c|}
\hline \multicolumn{8}{|c|}{ Sensitivity of Antibiotics Based on CLSI } \\
\hline \multirow{2}{*}{ Type of Bacteria } & \multirow{2}{*}{$\mathbf{n}$} & \multicolumn{3}{|c|}{ Ciprofloksasin } & \multicolumn{3}{|c|}{ Trimethoprim-Sulfametoksazol } \\
\hline & & S (\%) & I (\%) & $\mathbf{R}(\%)$ & S (\%) & I (\%) & $\mathbf{R}(\%)$ \\
\hline E.coli & 5 & $5(100)$ & $0(0)$ & $0(0)$ & $3(60)$ & $0(0)$ & $2(40)$ \\
\hline K. pneumoniae & 5 & $3(60)$ & $1(20)$ & $1(20)$ & $2(40)$ & $0(0)$ & $3(60)$ \\
\hline Enterobacter sp & 3 & $3(100)$ & $0(0)$ & $0(0)$ & $2(66,7)$ & $0(0)$ & $1(33,3)$ \\
\hline Citrobacter sp & 1 & $0(0)$ & $0(0)$ & $1(100)$ & $1(100)$ & $0(0)$ & $0(0)$ \\
\hline Total & 14 & $11(78,5)$ & $1(7,1)$ & $2(14,2)$ & $8(57,1)$ & $0(0)$ & $6(42,8)$ \\
\hline
\end{tabular}

Table 4 shows the results of the antibiotic sensitivity test showed that there were $8(57 \%)$ isolates resistant to antibiotics, ie $2(14.2 \%)$ isolates resistant to ciprofloxacin and $6(42.8 \%)$ isolates resistant to TMP-SMX. There were $11(78.7 \%)$ isolates sensitive to ciprofloxacin, $8(57 \%)$ isolates sensitive to TMP-SMX and $5(17.9 \%)$ isolates sensitive to both antibiotics. 


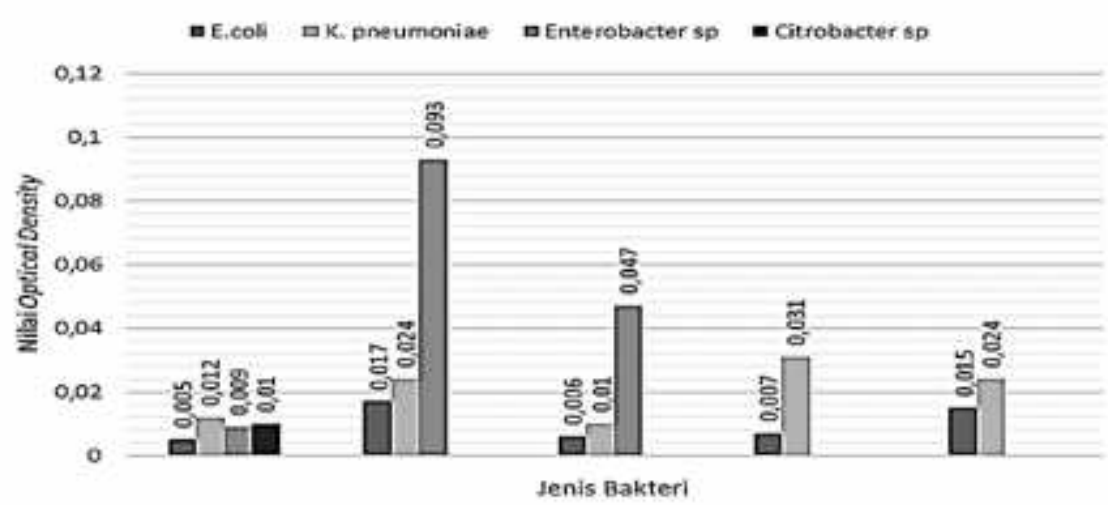

Figure 1 shows the results of examination of biofilm formation using Tissue Culture Plate method with ELISA readings obtained the range of optical density (OD) value of 14 isolates is 0.005-0.093 $(<0.120)$ so 14 isolates are categorized non / weak ie having weak ability in forming biofilm.

Table 5 Relationship of Biofilm Formation with Antibiotic Resistance Ciprofloxacin

\begin{tabular}{|c|c|c|c|c|c|c|c|c|}
\hline \multirow{2}{*}{$\begin{array}{l}\text { Biofilm Gram } \\
\text { Negative } \\
\text { Bacteria }\end{array}$} & \multicolumn{6}{|c|}{ Diameter of Ciprofloxacin Inhibitory Zone $(\mathrm{mm})$ Based on CLSI } & \multirow{2}{*}{$\begin{array}{c}P \\
\text { value }\end{array}$} & \multirow{2}{*}{$\mathbf{r}$} \\
\hline & $\begin{array}{c}\geq 20 \mathrm{~mm} \\
\text { (n) }\end{array}$ & $\%$ & $\begin{array}{c}\text { 16-20 mm } \\
\text { (n) }\end{array}$ & $\%$ & $\begin{array}{c}\leq 15 \mathrm{~mm} \\
\text { (n) }\end{array}$ & $\%$ & & \\
\hline$<0,120$ & 11 & 78,6 & 1 & 7,1 & 2 & 14,3 & & \\
\hline $0,120-0,240$ & 0 & 0 & 0 & 0 & 0 & 0 & & \\
\hline$>0,240$ & 0 & 0 & 0 & 0 & 0 & 0 & 0,501 & $-1,96$ \\
\hline Total & 11 & 78,6 & 1 & 7,1 & 2 & 14,3 & & \\
\hline
\end{tabular}

Table 5 shows $11(78.6 \%)$ isolates that are sensitive, $1(7,1 \%)$ intermediate and $2(14,3 \%)$ resistant to ciprofloxacin antibiotics and have weak (weak) ability to form biofilms. Based on bivariate analysis with Rank Spearman correlation test got correlation coefficient value equal to $1,96(\mathrm{r}<0,25)$ with value of significance / $\mathrm{p}$-value equal to 0,501 . Because the value of correlation coefficient $-1,96(<0,25)$ hence relation of formation of biofilm of gram negative bacteria with ciprofloksasin antibiotic resistance is very weak, insignificant and counterclockwise (if stronger biofilm formation then ciprofloksasin antibiotic resistance will be low or vice versa).

Table 6 Relationship of Biofilm Formation with TMP-SMX Antibiotic Resistance

\begin{tabular}{|c|c|c|c|c|c|c|c|c|}
\hline \multirow{2}{*}{$\begin{array}{l}\text { Biofilm Gram } \\
\text { Negative } \\
\text { Bacteria }\end{array}$} & \multicolumn{6}{|c|}{$\begin{array}{c}\text { Diameter of TMP-SMX Inhibitory Zone (mm) Based on } \\
\text { CLSI }\end{array}$} & \multirow[t]{2}{*}{ P value } & \multirow[t]{2}{*}{$\mathbf{r}$} \\
\hline & $\begin{array}{c}\geq 16 \mathrm{~mm} \\
\text { (n) }\end{array}$ & $\%$ & $\begin{array}{c}\text { 11-15 mm } \\
\text { (n) }\end{array}$ & $\%$ & $\begin{array}{c}\leq 10 \mathrm{~mm} \\
(\mathrm{n})\end{array}$ & $\%$ & & \\
\hline$<0,120$ & 8 & 57,1 & 0 & 0 & 6 & 42,9 & \multirow{2}{*}{0,721} & \multirow{2}{*}{0,105} \\
\hline $0,120-0,240$ & 0 & 0 & 0 & 0 & 0 & 0 & & \\
\hline
\end{tabular}




\begin{tabular}{lcccccc}
$>0,240$ & 0 & 0 & 0 & 0 & 0 & 0 \\
\hline Jumlah & 8 & 57,1 & 0 & 0 & 6 & 42,9 \\
\hline
\end{tabular}

Table 6 shows 8 (78.6\%) isolates that are sensitive, and $6(14.3 \%)$ are resistant to TMP-SMX antibiotics and have a weak (weak) ability to form biofilms. Based on bivariate analysis with Rank Spearman correlation test got correlation coefficient value equal to $0,105(\mathrm{r}<0,25)$ with value of signifikansi / p-value equal to 0,721 . Because the correlation coefficient value of $0.105(<0.25)$ then means the relationship of biofilm formation of gram-negative bacteria with TMP-SMX antibiotic resistance is very weak, not significant and unidirectional (if the stronger biofilm formation, the higher the TMP-SMX antibiotic resistance).

\section{Discussion}

In this study, the age of respondents with asymptomatic UTIwere above 50 years. The results of this study are consistent with the study conducted by Reddy et al. (2013) and Sakyi et al., (2013), who found the incidence of UTI in patients with DM occurred on ages over 50 years and 9 respondents $(25.7 \%)$ has stopped menstruation (menopause). It is associated with hormonal factors in postmenopausal conditions that cause vaginal atrophy, so the normal vaginal flora is reduced, $\mathrm{pH}$ increases and facilitates colonization of pathogenic bacteria in the urinary tract $^{8}$.

The results obtained 8 respondents (34.8\%) with UTI suffering DM $<5$ of the year. These results are in line with the Saptaningsih (2012) and Srinivas et al., (2014) studies which reported no association with duration of DM with $\mathrm{UTI}^{8,9}$. The results of different studies reported by Divyashree and Yadav (2015) and Boyko et al. (2005) found a relationship between the duration of DM and the incidence of UTI. The duration of DM can not be an indipendent factor of UTI, but is closely related to hyperglycaemia as experienced by respondents in this study who have high fasting blood sugar level and without fasting. The condition of hyperglycemia causes neurogenic bladder resulting in the unreliability of urinate and a good medium for bacterial growth and development ${ }^{11,12,7}$.

There were 10 respondents $(35,7 \%)$ with UTI having BMI overweight. These results are in line with research by Ariwijaya and Suwitra (2007) and Al-Rubeaan et al (2013) who reported an association between BMI overweight and UTI in DM patients. The condition of overweight / obese leads to insulin resistance, coupled with the state of hyperglycemia so that pancreatic beta cells are unable to produce sufficient insulin resulting in glycosuria which will be a good growth medium and breeding for pathogenic bacteria causing infection ${ }^{9,4,13}$. In addition, the patient's abdominal circumference $>80 \mathrm{~cm}$. An abdominal circumference of $>80 \mathrm{~cm}$ indicates a buildup of perivesical fat. Visceral fatty acid causes inflammatory epithelium causes urinary tract symptoms such as increased 
frequency and urinary urgency, coupled with the symptoms of polyuria in DM patients that facilitate pathogenic microorganisms to enter the urinary tract, then colonize and cause UTI ${ }^{14}$.

The results of this study also illustrated that 9 respondents (36\%) with the UTI sexual intercourse $<3$ times a week. The frequency of sexual intercourse $>9$ times in the last 1 month has a chance of 10 times having a UTI, while the frequency of sexual intercourse 4-8 times a month has 56 times experienced UTI. Ariwijaya and Suwitra (2007) study reported that UTIs in DM women were more common in sexually active respondents. During intercourse microorganisms present in the urethra or around the perineum may migrate into the urinary tract ${ }^{4,9}$.

Prevalence asymptomatic UTI in women DM T2 was found to be $31 \%$. This proportion is in accordance with a study reviewed by Renko et al. (2011) which states the incidence is $15 \%-30 \%$. The results of this study support the theory that UTI in women DM T2 is asymptomatic (no symptoms) ${ }^{15}$. Among the mechanisms that contribute to UTI in women DMT2, such as shorter urethra, high urinary glucose levels that facilitate the growth of pathogenic bacteria, low levels of IL6 and IL-8 (as the body's defense mechanisms to destroy pathogenic bacteria), Tamm- Horsfall plays an important role in preventing the attachment of pathogenic bacteria to uroepithelial and virulence factors from pathogenic bacteria itself $\mathrm{f}^{7,16}$.

The results of this study are in line with research conducted by Genghesh et al., (2009) in Libya which gained as much as the proportion of E.coli and $K$. pneumoniae as a cause of predominant UTI ${ }^{17}$. The bacteria Escherichia coli and Klebsiella pneumoniae are gram-negative bacteria enterobactericeae class which is one of the normal flora in the colon that can colonize in the urinary tract ${ }^{18}$. Both bacteria have the ability to colonize in the urinary tract with the help of adherence factor called adhesin. Adhesin will increase the ability of bacterial attachment to the urinary tract mucosa and also increase its virulence ${ }^{18}$. Shorter urethral size, sexual activity and lack of hiegine may be a predisposing factor of bacteria causing bacteria to colonize the vaginal introitus and then enter the urinary tract through the urethra and then ascending infections to the bladder, ureter, and renal parenchyma ${ }^{18}$.

Most of the microorganisms isolated in this study are still sensitive to ciprofloxacin and show that these antibiotics are still effective as first-line therapy in treating urinary tract infections. The results of this study in accordance with research conducted Nigussie and Amsalu (2017) in Ethiopia obtained a high level of resistance to TMP-SMX (64.7\%), and low resistance to ciprofloksasin $(23.5 \%)$ by isolated gram-negative bacteria in this study ${ }^{19}$. In this study there were no bacterial isolates resistant to both antibiotics (ciprofloxacin and TMP-SMX), these findings are different from previous studies that found high resistance to more than one antibiotic by the gram-negative bacteria 
causing UTI, including research in Ethiopia (93.9\%), Gondar (91.7\% -95\%), and Addis Ababa $(92.34 \%)^{19}$.

Gram-negative bacterial resistance to TMP-SMX antibiotics in this study may occur because these antibiotics are widely available first-line therapy and are often used in public health services such as Puskesmas, for either UTI or other infectious diseases. There is also the role of causal microorganisms capable of producing PABA and excessive dihydrofolate reductase enzymes that are able to inhibit the action of the TMP-SMX drug that causes resistance ${ }^{19}$. Ciprofloxacin resistance may occur due to mutations that cause target changes in DNA gyrase enzymes and DNA topoisomerase IV as well as plasmid-mediated resistance that can transmit resistant genes so that the initially resistant bacteria become resistant ${ }^{20}$. Antibiotic resistance is a global public health problem that can occur due to the availability of abundant antibiotics in health facilities as well as the use of irrational antibiotics, such as improper doses, inappropriate indications, incompatible with causal microorganisms, and pathogenic microorganisms that are able to form biofilms ${ }^{19}$.

The results of this study differ from studies conducted by Sayal et al. (2016) to obtain the results of the formation of biofilms that vary (non / weak, moderate and strong) ${ }^{21}$. Biofilms can be formed by almost all (99.9\%) microorganisms on various surfaces (biological and non-biological), with different optical densities. The ability of gram-negative bacteria to form biofilms depends on several adhesion factors and their virulence genes such as fimbriae, toxin, LPS (Lipopolysaccharide) , protein secretions, capsules, etc. Fattahi et al. (2015) study found that gram-negative bacterial isolates expressing pap $C$ and fim $H$ virulence gene encoded by type $\mathrm{P}$ and type 1 fimbriae were able to form a strong category biofilm compared with those not expressing the virulence genes. The involvement of bacterial virulence gene expression in attachment and biofilm formation, which indicates that bacteria is capable of forming strong / moderate biofilms are more pathogenic than non-weak in forming biofilms ${ }^{22}$. Another study by Wood (2009) found that the excess of c-GMP protein secretion by bacteria was associated with biofilm formation, this protein enhances bacterial ability to organize/ coordinate bacterial changes from planktonic form to sessile (biofilm) ${ }^{23}$.

The result of this study are not in line with research conducted Priyadharshini et al (2008) in Pakistan who found that bacteria isolated from DM patients had high levels of resistance against TMP-SMX antibiotics with moderate sensitivity to ciprofloxacin antibiotics. Of the resistant E.coli isolates $40 \%$ of the isolates were able to form biofilms ${ }^{24}$.Another study by Priyadharshini et al., (2014) in India found from 56 isolated bacteria, 37 (66\%) isolates were able to form biofilms, 15 $(40 \%)$ isolates resistant to antibiotics. While 19 other isolates that were unable to form biofilms were still sensitive to all antibiotics used in the study ${ }^{24}$. A study by Alves et al (2014) found that of 58 isolates capable of forming biofilms, $44.8 \%$ isolates were resistant to some antibiotics compared with 
$28.6 \%$ isolates with resistance from 98 isolates that were unable to form biofilms. This incident shows that biofilm formation increases the incidence of resistance to antibiotics ${ }^{25}$.

In this study found all the bacteria isolated to form biofilm with the category of weak (non/ weak). Biofilm is one of the bacterial self-defense mechanisms that is also associated with antibiotic resistance, but the bacteria that make up the strong category of biofilm are more resistant to antibiotics than the non/ weak categories. This is related to the expression of virulence genes (adhesion factor genes) of each bacteria that determine its ability to form biofilms. Some studies suggest that gram-negative bacteria that cause UTIs expressing the FimH gene and papC (type 1 and type $\mathrm{P}$ fimbriae) are able to form biofilms of moderate to strong categories, compared with those not expressing the gene. Fimbriae type 1 and type $\mathrm{P}$ is a filamentous structure composed of proteins located on the surface of bacterial cells and encoded by the genes of chromosomes. This structure can stimulate uroepithelial cell inflammation, facilitate bacterial invasion and form biofilm. It is also aided by the presence of c-GMP protein in the production of bacteria that organizes / coordinates bacterial changes from planktonic form to sessile ${ }^{22,23}$.Conventional antibiotics TMP-SMX and ciprofloxacin show a high percentage of resistance even in isolates that are unable to form biofilms. This may be possible because of the excessive and inappropriate use of antibiotics that accelerate bacterial evolution and provide a bacterial response to survive so that bacteria that are initially sensitive to an antibiotic, are less sensitive or even insensitive (resistant). Bacterial factors such as the presence of genetic mutations or the expression of resistant genes that result in the change of antibiotic "target site" against bacteria and the difference of virulence genes associated with biofilm formation causing antibiotic resistance ${ }^{25,26}$.

\section{Conclusion}

1. There is a weak association between biofilm formation by gram-negative bacteria with TMPSMX antibiotic resistance and ciprofloxacin.

2. The bacterial profiles of asymptomatic UTIs found in this study were E. coli (35.7\%), K. pneumoniae (35.7\%), Enterobacter sp (21.5\%) and Citrobacter sp (7.1\%). All 100\% isolated bacteria were able to form biofilm in the non / weak category with an OD value of $0.005-0.093$ $(<0.120)$

3. There were $8(57 \%)$ isolates resistant to antibiotics, ie $2(14.2 \%)$ isolates to ciprofloksasin caused by K. pneumoniae ( 1 isolate) and Citrobacter sp (1 isolate) and 6 (42.8\%) isolates against TMPSMX caused by E. coli ( 2 isolates), K. pneumoniae ( 3 isolates) and Citrobacter sp (1 isolate). 
4. The incidence of asymptomatic UTI in DMT2 women in the work area of Puskesmas Mon Geudong Kota Lhokseumawe by $31 \%$.

\section{Suggestion}

1. Considering high number of asymptomatic UTI cases in DMT2 women, need for screening as a first step to detect UTI disease to prevent from developing the disease into symptomatic UTI and other kidney disease complications arise.

2. Although identified bacterial isolates have the ability to form weak category biofilms, High levels of resistance of TMP-SMX antibiotics as first-line therapy of UTI. Utilizing appropriate adjustment of random antibiotics is appropriate, appropriate dose, delivery method, indication in accordance with the causal bacteria infection based on bacterial culture sensitivity test. Using TMP-SMX antibiotics against newly exposed patients to first UTI and ciprofloxacin antibiotics to patients with recurrent UTIs to minimize the occurrence of resistance.

\section{Bibliography}

1. Rachman, N. O., Muhammad Darwin, P., \& Lia Yuli, B. (2016). Bacterial Sensitivity Test Causes Urinary Tract Infection in Diabetes Mellitus Patients Against: Ceftriaxone, Levofloxacin and Gentamicin. Medical periodical journal, 205-213.

2. World Health Organization. (2016). Diabetes Facts and Numbers. World Helath Diabetes Days.

3. Samuel, O. O., Mathew, A. O., Agboola, D., Joshua, O., Tosin, A., Grace, A. B., et al. (2014). Asymptomatic Urinary Tract Infection In Diabetic Patients In Ago -Iwoye, Ogun State, Nigeria. Journal of American Science, 72-78.

4. Ariwijaya, M., \& Suwitra, K. (2007). Prevalence, Characteristics and Factors Associated with Urinary Tract Infection in Inpatient Diabetes Mellitus Patients. Journal of Internal Medicine, 112-127.

5. Schneeberger, C., Kazeimer, B. M., \& Suzzane, G. A. (2014). Asymptomatic Bacteriuria And Urinary Tract Infections In Special Patient Groups: Women With Diabetes Melitus And Pregnant Women. Curr Opin Infect Dis, 27, 108-114.

6. Flores-Mireles, A. L., Walker, J. N., Caparon, M., \& Caparon, M. (2015). Urinary tract infections: epidemiology, mechanisms of infection and treatment options. Nat Rev Microbiol, 269-284. 
7. Nitzan, O., Elias, M., \& Saliba, B. C. (2015). Urinary Tract Infection in Patient with Type 2 Diabetes Melitus: Review of Prevalence, diagnosis and Management. Dovepress Journal, 129-136.

8. Hernandez, J. G. (2013). Doctoral Dissertation :Mechanism of Microbial - Host Interaction During Asymptomatic Bacteriuria. Sweden: Lund University.

9. Saptiningsih, M. (2012). Determinan Urinary Tract Infection Patient Diabetes Mellitus Women in RSB Bandung. Thesis. Master of Nursing UI.

10. Srinivas, A., Chandrashekar, U. K., Shivaskhankara, K. N., \& Pruthvi, B. C. (2014). Clinical Profile of Urinary Tract Infections in Diabetic and Non-Diabetics. Australasian Medical Journal (AM), 29-34.

11. Divyashree, K., \& Yadhav., K. (2015). Asymptomatic Bacteriuria and Associated Host Factors in Diabetic Patients with Special Reference to UTI Chromagar. International Journal of Medical Research and Review, 1218-1223.

12. Boyko, E. J., Fihn, S. D., Scholes, D., Abraham, L., \& Monsey, B. (2005). Risk of Urinary Tract Infection and Asimtomatic Bacteriuria among Diabetic and Nondiabetic Postmenauposal Women. Am J Epidemiol, 557-564.

13. Al-Rubeaan, K. A., Moharram, O., Al-Naqeb, D., \& RaWullah, A. H. (2013). Prevalence of Urinary Tract infection and Risk Factors among Saudi Patients with Diabetes. World J Urol, $573-578$.

14. Oliveira, M. C., Varella, L. R., Angelo, P. H., \& Micussi, M. T. (2016). The Relationship between The Presence of Lower Urinary Tract Symptoms and Waist Circumference. Diabetes Metab Syndr Obes., 207-211.

15. Renko, M., Tapanainen, P., Tossavainen, P., Tytti, P., \& Matti, U. (2011). Review/ Commentaries ADA Statement: Meta-Analysis of the Significance of Asymptomatic Bacteriuria in Diabetes. Diabetes Care, 34(1).

16. Reygaert, W. C. (2014). Innate Immune Response to Urinary Tract Infections Involving Escherichia coli. Journal of Clinical and Cellular Immunology, 1-5.

17. Genghesh, K. S., Elkateb, E., Berbash, N., Nada, R. A., Ahmed, S. F., Rahouma, A., et al. (2009). Uropathogen from Diabetic Patients in Libya: Virulence factors and Phylogenetic groups of Escherichia coli Isolates. Journal of Medical Microbiology, 1006-10014.

18. Sobeiszczyk, M. E. (2009). Urinary Tract Infection. Dipetik September 17, 2017, dari columbia.edu: http://www.columbia.edu/itc/hs/medical/pathophys/id/2009/utiColor.pdf

19. Rahmad, B. (2017). Thesis: Isolation and Identification of Ciprofloxacin Resistance Genes in Isolate Escherichia coli Multidrug Resistance of Persons with Urinary Tract Infection in 
Abdoell Moeloek Hospital Lampung Province. Post Graduate Program Master of Chemistry Faculty of Mathematics and Natural Sciences.

20. Nigussie, D., \& Amsalu, A. (2017). Prevalence of Uropathogen and Their Antibiotic Resistance Pattern among Diabetic Patients. Turkish Journal of Urology, 85-92.

21. Sayal, P., Devi, P., \& Singh, K. (2016). Bacterial Colonization and Biofilm Formation among Diabetic Patients: A Therapeutic Challenge Int.J.Curr.Microbiol.App.Sci, 174-181 .

22. Fattahi, S., Kafil, H. S., Nahai, M. R., Asgharzadeh, M., Nori, R., \& Aghazadeh, M. (2015). Relationship of Biofilm Formation and Different Virulence Genes in Uropathogenic E. coli Isolated from Northwest Iran. GMS Hyg Control, 1-7.

23. Wood, T. K. (2009). Insight on E.coli Biofilm Formation and Inhibition from Whole Transcriptome Profiling. HHS Public Access Environ Microbiol, 1-15.

24. Priyadharshini, A., Mangaiyarkarasi, Balasubramaniam, Pragash, D. S., \& Gopal. (2014). Biofilm Production and Antibiotic Resistance among Uropathogens Causing Bacteriuria in Diabetic Individuals. Scholars Journal of Applied Medical Science (SJAMS), 568-571.

25. Alves, M. J., Barreira, J. C., Carvalho, I., Trinta, L., Pereira, L., Fereira, I. C., et al. (2014). Prospensity for Biofilm Formation by Clinical Isolates from UTI: Developing a Multifactorial Predictive Model to Improve Antibiotheraphy. Journal of Medical Microbiology, 471-477.

26. Yenny, \& Herwana, E. (2007). Resistance ofEnteric Bacteria: Global Aspects of Antimicrobials. Universa Medicina, 46-56. 